\title{
'From London to Los Angeles: A Comparison of Local Labour Market Processes in the US and UK film industries'
}

\author{
Helen Blair \\ Royal Holloway (University of London) \\ School of Management \\ Egham \\ Surrey TW20 0EX \\ UK \\ h.blair@rhul.ac.uk \\ Tel: +44 (0)1784 414348
}

Nigel Culkin (University of Hertfordshire)

Keith Randle (University of Hertfordshire)

Business School

Mangrove $\mathrm{Rd}$

Hertford, SG13 8QF

UK

Email: ‥Culkin@ herts.ac.uk; $\underline{\text { K.R.Randle@ @erts.ac.uk }}$

Tels: +44 (0)1707 285492; +44 (0)1707 285445 
'From London to Los Angeles: A Comparison of Local Labour Market Processes in the US and UK film industries

\begin{abstract}
Addressing the issue of the embeddedness of labour markets, this paper compares the processes of finding employment in the film industry within two local labour markets. Drawing on studies of freelance film crew in the London (UK) and Los Angeles (US), the paper concludes that the importance of social networks in job mobility in both contexts is a consequence of common production structures. However that common labour market practice varies in each geographical space as industry processes and structures are mediated by local institutional contexts.
\end{abstract}

\title{
Acknowledgements
}

We would like to thank Jane Hardy of the Employment Studies Research Unit at the University of Hertfordshire Business School for her comments on an earlier draft of this paper. 
'From London to Los Angeles: A Comparison of Local Labour Market Processes in the US and UK film industries

\section{Introduction}

Addressing the issue of the embeddedness of labour markets, this paper compares the processes of accessing employment in the film industry within two local labour markets. The dominant understandings of labour market processes in the film sector neglect to address the emdeddedness of local labour markets in geographically specific institutional configurations (e.g. Jones 1996). Drawing on embeddedness and local labour market theory (Granovetter (1985) and Peck (1996) respectively), the experiences of two groups of film industry freelances in Los Angeles (USA) and London (UK) are examined to interrogate the effects of varying institutional configurations on labour market experiences. Recent developments in the field of economic geography (e.g. Peck 1996) argue that the production, reproduction and regulation of labour market processes are locally embedded. The segmentation and structuring of labour market process are understood, therefore, as spacially contingent (Peck 1996: 5). The similarities and differences observed in workers experience of, and strategies for, gaining access to the labour market and remaining in regular employment confirm the effect of spatial contingency, indicating that common industry structures are played out slightly differently in each local context.

In outlining this argument and the empirical evidence in its support, we firstly introduce the concept of embeddedness as a contrast to the neoclasically influenced competency approach of influential film industry commentators. Having briefly 
presented a case for the social constitution of the labour market, we then consider the geographical contingency of local labour markets and argue the importance of considering variations in practice and behaviour at a local level. Concretising this, we introduce the institutional contexts of the London and Los Angeles film labour markets and raise points of contrast and comparison. The empirical section of the paper reports trends emerging in the Los Angeles and London film labour markets by examining the processes of accessing and remaining in active employment. In conclusion the implications of these empirical observations for existing approaches to labour market processes in project-based sectors are commented upon.

\section{Labour Market Strategies in Project-Based Sectors and Local Labour Markets}

In studies examining employment in project-based industries, such as the film industry, the importance of informal, interpersonal networks is identified as critical to receiving information and securing jobs (e.g. see Christopherson and Storper (1989) and Randle and Culkin (2000) for US studies and Blair, et al. (2001) and Langham (1996) for UK studies). While this presents a specific and concrete incidence of interpersonal network use, the notion that individuals are embedded in social networks in all spheres of their life and that these networks influence individual's behaviour was influentially conceptualised by Granovetter (1985). As he strongly asserts to view action as independent of social structures is a "a grievous misunderstanding" (1985: 482). Individuals operate in socialised contexts, within sets of social rules and criteria of social legitimacy which in part define their functioning and measure their success. 
The common and explicit reliance on social networks in the film industry is due to the structural organisation of production as temporary, project organisations and a requirement for reliable labour in those uncertain conditions (Blair 2001a, 2001b, Pfeffer 1976). Notwithstanding the social nature of this process, Jones and DeFillipi (1996) apply a competency-based understanding of career development to freelance careers, drawing on the concept of the 'boundaryless career' (DeFillipi and Arthur 1994, Jones and Walsh 1997). This concept is built around individuals' human capital accumulation as they move, apparently unconstrained by organisational boundaries, between different work projects.

The usefulness of this approach to understanding how freelances access employment is however, questionable. Jones and DeFillipi (1996) contend that a combination of competencies is required in order to be 'successful' in the labour markets of projectbased industries. The general thrust of the argument is that those who acquire competencies, such as industry knowledge and skills (Jones and DeFillipi 1996: 101), in greatest 'measure' will be able to leverage them in the marketplace. So success in the labour market is determined by investments in human capital of varying types and individuals will accrue benefits in keeping with their 'investments'. Jones and DeFillipi's (1996) neoclassically influenced model reduces the importance of structural influences on the acquisition of contacts or knowledge (Doeringer and Piore 1971) and the systematic structuring by institutional forces and power relations of the labour market itself.

The consideration of labour market processes as embedded in specific labour market and wider institutional configurations provides a more structurally grounded basis 
from which to understand the processes of getting work. As regulation theorists would identify, this suggests that labour market strategies are in part conditioned by the dynamic interplay between demand, supply and regulatory influences (Boyer 1990, Picchio 1992, Rubery 1994). The institutions of the labour market, and social processes that contribute to their replication, while varying in different contexts are a major influence on the behaviour of those seeking and securing work and in the film sector. As in other industries, supply and demand is co-ordinated to a greater extent through social processes than the price mechanism (see Grieco 1987, Granovetter 1995, Wial 1991).

This social process argument has been applied to the experience of film producers in the Canadian film industry (Coe 2000). Coe (2000) situates the development of the film industry in Vancouver within international, national and regional levels of analysis, addressing the influences of institutions such as US multinationals, government and broadcaster policy, and local interpersonal networks on that development process. He argues that producers are embedded in networks of interpersonal relations that are mobilised to realise the material goal of film production. For example, although the film and television market in Vancouver is dominated by US producers, distributors and exhibitors (constraining the development of the indigenous industry) local producers can, however, utilise their relationships with those organisations to finance their local projects. Fundamentally, therefore, labour markets are structured by social processes, not impersonal, disembodied market forces (Edwards 1979, Gordon, et al. 1982, Polyani 1944). We would expect to find therefore that the processes of finding employment in the film sector in 
London and Los Angeles is governed to a great extent by interpersonal social processes.

Rather than a rational acquisition of various forms of capital being the driver of labour market strategies, individuals utilise personal contacts predominantly to begin and develop careers in such contexts (Blair, et al. 2001, Christopherson and Storper 1989). As empirical evidence would seem to confirm (Blair, et al. 2001), the core of the competency model is fundamentally weakened because investment in education or training may be ineffectual without the social contacts to leverage that knowledge and skill. However, the social shaping of the labour market gives rise to variations in structures and processes as a consequence of embeddedness in different institutional settings.

Following from the embeddedness argument outlined above, Peck contends that labour markets are systematically structured by institutional forces and power relations (1996: 5). In geographical spaces unique configurations of social processes intersect and generate a set of social processes that are particular to that location (ibid). Therefore labour markets vary over space as well as time. Labour market processes, while situated in a wider national context, are local in that they are the product of a production-reproduction dialectic which is locally defined by that unique configuration of institutions. The 'localness' of the labour market is defined as "the scale at which labor is mobilized on a daily basis and at which some of the most important reproduction functions are sited" (ibid: 264). So for example, there are local variations in labour market strategies in terms of their structure and function, and which draw on local embedded tacit knowledge and training (Rubery 1994). As such, 
it is anticipated that the differences in the local institutional settings of London and Los Angeles will give rise to differences in local labour market processes in each location.

If it is accepted that labour markets are regulated by social processes as opposed to the price mechanism, and that labour is social in nature, then labour markets must be expected to vary in structure and operation across different geographical spaces as the institutions and social processes governing them vary (Peck 1996: 11). However, this cannot be characterised simplistically as a based on different national systems of labour regulation. The processes of reproducing labour and its consumption within the labour process interact at a local level to produce distinctive variations in labour market dynamics and characteristics. Therefore, it is not only at the national level that labour markets can be argued to vary, but also within nations given the interaction of geographically specific forms of social regulation which contribute to the shape and form of the labour market. It is for this reason that London and Los Angeles labour markets are referred to specifically within the paper. The London labour market in the film industry is different in many ways from that of other regions of the UK, as can be said of the Los Angeles and New York film labour markets (Christopherson 1996).

Significantly, as Peck notes 'Places are different, but they also have shared features' (1996: 14) and so his argument is not of extreme geographical specificity. Rather generalised industrial and regulative processes he argues instead, have different concrete effects in different places as a result of their mediation through varying institutional contexts. Generalised processes such as globalisation, or industry trends and dynamics do not become any less important in analysis, but are considered to be 
general processes that are locally mediated. What is taken into account is the interaction of local, industry and global social and economic forces, each of which are concerned with the consumption of labour power within the labour process. For example, in the film industry there are common production structures which result in the formation of a labour market dominated by freelances in many regions of the world. Given these common structures, we would anticipate there to be some similarity of labour market processes in Los Angeles and London and well as locally mediated differences.

\section{The Context of the London and Los Angeles Film Industries}

In this section the contexts of the Los Angeles and London film labour markets are described. While there are significant similarities, as indicated conceptually in the previous section, there are also a number of variations that can be seen to influence the behaviour of freelances in the labour market. So, the industry structures and institutions of each local context are compared and contrasted to enable an analysis of freelancer's approaches to getting work in each local labour market.

\section{Industrial Structure}

In both the American and British film industries film production is now organised on a project-basis. The resources required to produce a film are assembled for, and dissembled after, each film is produced (see Christopherson and Storper 1989, DeFillippi and Arthur 1998 for US references; Ellis 1992, Langham 1996 for UK references). The result of an industrial structure described by Christopherson (1996) as 
'virtually integrated' is the legal, but not economic, separation of the firms involved in the production, distribution and exhibition of films. The workforce in both national film sectors is predominantly freelance, with work patterns comprising short-term employment on discrete film projects (Blair, et al. 2001, Gray and Seeber 1996, Skillset 1996). Production companies recruit on a project-by-project basis and so, typically, film freelances experience high levels of structured employment uncertainty. Christopherson (1996) describes the negative implications of this emerging structure for the maintenance of a skilled labour force and the role played union locals in Los Angeles in developing new institutions to carry out critical functions (see below).

It is generally accepted that the production sector of the British film industry is fragmented, frequently being described as a 'cottage industry' with small, undercapitalised companies undertaking discrete component activities of the film making process (see for example BECTU 1994, Film Policy Review Group 1998, PACT 1994). The current wave of merger activity among UK and European media companies is slowly beginning to generate greater concentration and some vertical integration (Blair and Kerrigan 2001, Whitney 2001). By contrast, the US industry is, and has historically been, highly capitalised and structured around integrated 'majors' like MGM, Twentieth Century Fox and Warner Bros. that provide greater stability in film financing. The similarities of industrial structure and production organisation could be expected to cause similarities in labour market processes.

\section{Industrial Relations Landscape}

Distinct differences exist between the industrial relations landscape in the London and LA film industries, with the respective unions operating different internal structures 
and bargaining structures. The UK entertainment industries union, BECTU (Broadcasting Entertainment Cinematograph and Theatre Union) has some 26,000 members across the film, television and other media sectors (BECTU 2000) and is organised nationally along industrial lines. Industry-wide agreements in minimum pay and working conditions (hours, holiday entitlement etc.) are negotiated between BECTU and the employer's association, PACT (Producers Alliance for Cinema and Television). Within this agreement minimum pay levels are set for each grade within each skill group. However, BECTU plays a limited role in negotiating individual member's employment relationships with employers as many productions are made outside that industry agreement. The UK union also provides services and benefits for individual members (e.g. careers advice service) and representation when called upon to do so.

Unlike its US counterpart IATSE (International Alliance of Theatrical Stage Employees), BECTU has played a negligible role as a 'labour agency', or in processes of labour allocation. IATSE, adopted a federated craft union model (Gray and Seeber 1996) and developed a roster system ensuring that previously studio employed personnel were given priority access to employment opportunities on a seniority basis. During the 1950s in the USA the roster system was supported by the major studios, as it served as a certification and screening device for labour while allowing them to shed overhead costs. BECTU, by contrast forthrightly opposed the move towards freelance employment and has not adopted a similar labour agency function. It did, however, regulate the aggregate level of labour supply at an industry level by controlling access to work via a union membership prerequisite until the end of the closed shop through national legislation in 1982. The union's bargaining position and 
influence was severely reduced by that legislative change and the various unions that later merged to form BECTU suffered marked losses in membership. The US entertainment industry as a whole, by contrast, is highly unionised, although patterns of unionisation are changing, as above the line unions ${ }^{\mathrm{i}}$ have been growing while below the line membership has fallen (see also Paul and Kleingartner 1994). This latter tendency is accounted for by both technological change and moves towards nonunion production in some sectors (Gray and Seeber 1996). However, a de facto closed shop still operates on large budget studio productions (those tending to be the highly paid, prestige projects on which most freelances aspire to work) or under specific union agreements with regional employers associations (Gray and Seeber 1996). As a result, US freelances still aspire to union membership, which requires certain skill and employment activity levels to be met as a pre-requisite. By contrast union membership in the UK is open to both those active in the industry and aspirants (BECTU 2000) and union membership no longer forms an employment prerequisite.

The US roster system allowed craft unions to control labour supply and maintain seniority rights. The residual impact of this is that employment may be secured differently in the US, at least among the major production companies. The smaller, independent, and generally lower budget productions, tend to be non-union, while the unions focus their attention on ensuring that larger budget productions come under union contracts. New entrants to the industry will experience extreme difficulty in gaining entry to the larger, better paid and unionised productions as they will be unable to provide evidence of sufficient paid work to satisfy union membership requirements. This has tended to produce a system of 'industrial apartheid' with the two levels of employment having different associated terms and 
conditions. Nevertheless both levels still draw upon highly informal methods of recruitment and selection.

IATSE also administers a health and pension scheme (The Motion Picture Health and Welfare Fund) independent of any given employer and a system of supplementary payments (residuals) related to the profit life of the product (Gray and Seeber (1996); see Paul and Kleingartner (1994) for above the line union involvement in residual distribution). Given the variation in labour institutions in London and Los Angeles, it is expected that the process of finding and securing work will differ in the two locations.

\section{Training and Education}

The 'vertical disintegration' that characterised changing industrial structure, meant that skills had to be acquired over an extended period of intermittent project work, rather than through continuous employment in a studio for both London and Los Angeles based freelance crews. While US craft unions were able to continue to control the supply of labour throughout this process, those undertaking apprenticeships were subject to greater hardship. Eventually, however, as potential entrants to the industry became increasingly frustrated, new technology was introduced, and employers objected to the conditions surrounding labour supply, film and television schools developed to become the primary provider of skills in these industries (Gray and Seeber 1996). In the UK by comparison, film schools remain small and often elite institutions, training a smaller proportion of the total workforce. The majority of skills training now takes place on-the-job, rather than via formally planned training as traditional training providers such as public service 
broadcasters have lessened their training role. Variations in access routes to the industry via training and educational institutions are liable therefore to result in different approaches to accessing work in the film sector.

\section{Research Method}

Before reporting the empirical data which points to the social processes that coordinate the local labour markets concerned and illustrate the differences in labour market processes as a result of geographical location, the research methods adopted in each of the studies are outlined below.

\section{The UK: TeenComedy Case Study}

The empirical data from the UK is drawn from a case study of a film production. TeenComedy ${ }^{\mathrm{ii}}$ was tracked over a period of 18 months through the production process: pre-production, production, post-production, marketing and distribution to the release of the film. The case production conforms structurally to patterns of production and industrial organisation evident in the UK film sector. Furthermore, due to the structuring of film production along project lines, TeenComedy employed a crew with wide industry experience through employment on a large number of film and television projects.

The use of multiple data collection methods in conducting the case study facilitated an in-depth examination of the production and labour allocation processes, and so provided an empirically rich analysis of the dynamics of the film production process and employment. Observation, interviewing and a questionnaire survey were the main 
data collection methods employed. The period of observation was of five-months duration, involving attending all production meetings and being present with the crew on a daily basis during principal photography. A questionnaire survey was administered to the crew to gather information concerning their employment patterns and labour market processes. Finally, twenty in-depth, semi-structured interviews were conducted with crew members (from different departments and at varying organisational levels) following principal photography, enabling the themes and issues arising from the observation period to be probed further. It is this data that are reported predominantly here. Pseudonyms have been used in the reportage of both data sets to protect interviewee's anonymity.

\section{The US: Panel Study of Freelance Employees}

The US data was gathered from a panel study of freelance workers in the Los Angeles area. This longitudinal approach involved the establishment of a set of base measures, including background and routes of entry, followed by a succession of follow-up interviews focussing on the degree of success of these individuals in establishing and developing their careers in the industry. As freelance workers represent a particularly disparate group, individuals were initially contacted using electronic mail (email) based on a searchable database (http//www.crewnet.com). This represents an innovative and effective method for collecting data relating to the subject group, and we have described the research method involved in some detail elsewhere (Randle and Culkin 2000).

In the first phase of the study (July 1999) a range of occupations key to the production phase were targeted and randomly selected individuals in the LA area were invited to 
take part. This approach secured a good response and twenty-three in-depth interviews were carried out with freelance workers. The second phase of the study took place in July 2000. Follow-up interviews were conducted with eighteen of the original panel members in addition to new members being added to the panel to represent occupations not previously included. In addition to searching the CrewNet database once again, we also made use of a sampling technique known as 'snowballing' (Malhotra 1996), whereby the initial group of respondents provide names of individuals for future interviewing. Several interviews were also carried out with key members of the main IATSE affiliated labor unions covering wardrobe, camera, editing and grips.

\section{Building a Freelance Career - The UK and US Experience}

In this section the processes involved in gaining initial access to work in the film sector are presented, followed by an analysis of the processes utilised in maintaining regular employment in each of the local labour markets. In both studies the importance of building and maintaining a network of contacts was critical to progressing a career although the means of access to, and use of contacts, varies between the two groups.

\section{Getting In - The London-based, UK Film Labour Market}

When gaining access to the industry, the majority of the TeenComedy crew had a preexisting contact with someone in the industry. Overwhelmingly, they had heard about their first job in film or television through a friend or relative and, by contrast, a much 
smaller number had heard of their first job through directly writing to, or making contact with, companies (Blair, et al. 2001). Before personality traits and tacit or generic skills can be discussed, entrants require to know of people in the industry to approach about work, or a mediator to act as a conduit for information.

A family member can be the means through which the entrant gains exposure to, and develops an interest in a career in, the film industry. In very general terms that relative provides a link between an individual 'outside' the sector and one (possibly more) 'inside' as the following quote illustrates:

"on the nepotism side of it. My sister married a production manager when she was very young, in fact about 18, and got divorced after that but they stayed married just long enough for him to give me a couple of jobs on films as a freelance runner ... that was it then, I was off and running.” Adrian (Head of Department)

A friend working in the industry may serve a number of similar functions to assist in both disseminating information and gaining access to the first work opportunity:

"our best friend was corporate accountant to Eon Productions who produce the Bond movies. They had a cashier doing the payroll and the cashiering who wasn't really up to the job so I was offered three days a week on that doing the payroll. That very quickly snowballed to a full time job and I haven't looked back since basically.” Derek

John entered the industry

"Through a friend of mine. He was ... working for a very small lighting company in this industry and the industry was busy at the time and there were no electricians available ... so 
he was taking on people, just electricians. ... I was there two days and I was off out, out on the road lighting."

Actually getting that first job relied heavily upon being recommended by a third party (over half, some 30, of the TeenComedy crew got their first job by this means). The recommendation may, for example, take the form of a character reference and a statement of a person's eagerness to work in the industry. Detailed knowledge of the entrant, coupled with the obligation subsequently felt by the entrant (see also Grieco 1987), makes recommending the individual less of a risk to the family member/friend, enabling a more convincing case to be made on behalf of the entrant (see also Granovetter 1985). Furthermore, as the 'reference' comes from a familiar source, and will be presented by someone familiar with the values held in the industry, an employer may be more willing to give the recommended party a job than a stranger who may be perceived (rightly or otherwise) as a greater risk (Pfeffer, et al. 1976).

\section{Getting In - The Los Angeles Film Labour Market}

Those taking part in the US study worked in a range of different media industries and the routes interviewees had taken into the business were equally diverse. As in the case of the UK industry, family connections were seen as in important advantage:

"around here a lot of people got in ... uh because it was the family line of business ... I mean there's a huge, huge percentage of people who do this because their parents did it, one or both of their parents did it." David 
Many individuals reported having spent some time working for free or for 'deferred payment' (payment dependent on the market success of the film) as a means of 'resume building'. A now well-established script supervisor commented that;

"...you do a lot of work for free at the beginning because you have got to build your resume, I did three or four student films, a couple of shorts and one whole feature for free...but I haven't worked for free since the summer of 1996..." Karen

Those in work were conscious of the growing pool of aspirant film workers seeking entry into the industry, many coming through the film school route, who were prepared to work long hours for free or for 'copy and credit ${ }^{\text {iii }}$. Internships, another form of free working, are quite a common entry route to the industry, generally through one of the film schools, and take the form of an unpaid apprenticeship. A line producer describes how;

“... if you aren't born into the industry, or you're not married to or sleep with someone in the industry, or you don't find some other avenue of getting in, there are people that the only way they can get in is to intern or to PA. An intern means basically you're working for free..." Susan

This comment suggests that internships constitute a last resort for those who can not rely on some form of social contact to provide a route into the industry. In this case a degree of formalisation has come into play and the individual who has neither the 'know how' or 'know whom' to gain access is forced along a film school/ apprenticeship route in order to gain both types of knowledge. The following interviewee describes how working for free is necessary in order to gain access to 
contacts and how family support can underwrite that opportunity even when it cannot provide access:

"... I have also been very lucky to have a mother and father that have helped support a career in the film business. And I do have friends that are in the same boat. And its one of the things that unfortunately is really necessary .... is some way to finance the time that you have here ... because you're either going to be working for free to get experience, or you're going to be working for some pay, some free, or you're going to ... the bottom line is ... going to drop out ... and you're going to have to start taking a show for free, maybe it's a weekend show and you do it for free just to meet people which is what a lot of people do, and I've actually been ... I've thought about it when it gets lean, you know, its like, well maybe I should, just to get on the set and see people and make some new connections." Tudor

In some cases support from the family might involve direct handouts, though in others access to other forms of paid work might be critical. Working on student films, without necessarily attending film school oneself, constitutes yet another form of unpaid access to knowledge and contacts:

“... for the first five years it was really difficult to make a living because I didn't know anybody in the industry ... So I started out working for free doing student movies and getting experience and having the stuff to put on my resume, So I did that ... and then one of the student movies I had worked on ended up leading to a real job (laughs) ... the producer on that had ended up recommending me to a low budget .. a director/producer who was doing some low budget movie ... so that was my first paid position.” Karen 
In many cases those we spoke to indicated that sporadic work in the industry would be supplemented, or even sponsored by, other forms of part-time work either in parallel or between unpaid jobs. In practice it seems unlikely that any form of regular parttime work would be possible while working in the industry given the long and irregular hours worked by crews in production.

\section{Getting On - Developing a career in the UK Industry}

Given the brevity of periods of employment on projects, the early stages of a career are regarded as difficult. New entrants have few contacts on whom to draw for information or recommendations and it those informal social processes that continue to be the dominant access to information and work opportunities:

"I was working with a first [assistant director] ... and I'd worked with him just two weeks and his regular [in the next grade] was moving on, was offered something else. He [first assistant] thought he'd like to try someone new who would be kind of really enthusiastic and keen about something and so he asked me whether I'd like to do it. I would have stayed with [him] but he just didn't get any work and then out of the blue [my current HoD] rang me up and he'd needed someone, he didn't want to use the guy that he was normally using and he'd heard that I was free and so asked me. I met him (and I'd met him before on something else and not really worked with him directly) and so worked with him and he kept getting work so I stayed with him.” Liz

More formal mechanisms do exist for transmitting job information such as diarist services, agents and production listings but reliance upon these is secondary to the use 
of contacts. Passing information by means of recommendation is an important function played by contacts as the following typical quotation illustrates:

"I had worked with another production manager who suggested me and I had a short interview with [the head of department] and we started from there really.” John

This also infers the types of co-operative, information sharing behaviour that is common among freelances, which is also reflected in the US study, and which tends to refute the overly individualistic conceptualisations of Jones and DeFillipi (1996).

As careers continued, however, the type of contact used to get work altered. Family contacts became much less significant as individuals met people on different jobs and built a network of contacts themselves. The range of contact types used therefore expands as entrants accumulate, for example, a number of ex-colleagues who can potentially recommend their abilities. Once those contacts have been built, being asked onto a film or recommended by ex-colleagues becomes more common. Such ex-colleagues, if a relationship is maintained, can be important sources of recommendation (as they are aware of the individual's abilities and character) and information:

"I first worked with [current colleague] back in (pause) 88 I think ... and then he got a break [at the next grade] on a TV drama, and he said to me 'Would I like to [work] for him' and I said 'yea, sure'. Alan 
Other than occasional recommendations at opportune moments, more systematic, ongoing labour market relationships also exist between individuals. A more stable relationship may exist between individuals whereby the head of department would employ the same people on each job (a semi-permanent work group), or may have a small number of people whom s/he employs regularly (but not the same people on every job), or may 'mentor' a more junior freelancer. To be a part of a regular work group is a labour market position many freelances aspire to as it offers greater security of employment and more established working relationships:

“... you kind of spend a lot of time as a third $\mathrm{AD}$ [assistant director] kind of pointing or hoping to find your team, cos once you're in a team you're kind of set in that way" Liz

An example of a less regular but nonetheless ongoing relationship is given below, using the camera department as an example:

“... a cameraman might have two or three operators that he uses, who would have two or three focus pullers. So I mean the combinations are there that you can have different faces" Stephen.

Mentoring, whereby a more experienced film worker actively assists a more junior grade in a variety of career development areas (skills, know-how, contacts) is also an observable trend in both the US and UK:

“... and because he liked me ... then he [the mentor] basically got all my other jobs because [he] just recommended me to everyone. He was just fantastic, just completely launched me. 
So that's how kind of, how I got into it, but, a bit of luck and it was luck, you know, to get the right job and then getting other people to employ me." Liz

This type of mentoring behaviour again illustrates the co-operation which exists between members of the labour market and points to the requirement for a social explanation of labour market processes which incorporates both individual and collective action. Again, however, in order for this type of skill and contact development to occur, a relationship must exist through which the information and advice is passed.

Other than those contacts met through employment, contacts can also be accumulated through social gatherings of an industry and a personal nature. Organisations such as guilds, the film union (BECTU) and employers' association (PACT) provide seminars and events at which film freelances meet. Although not specifically instituted for networking purposes, such gatherings are often used by freelances for that purpose. Other social events such as parties are places where people meet and become acquainted with mutual friends. This is related more generally to the lifestyle of people working in the film industry and the, to a considerable extent, industry bound social circles in which they move.

\section{Getting on in the US industry}

A recent text aimed at those aspiring to enter the US entertainment business emphasises that while an element of luck and access to a mentor may be important, 'networking' is central to achieving a successful career (Tepper 1999: 15). Our 
interview subjects acknowledged the centrality of their networks to their ability to find work;

“...if I'm looking for work there's five people I call and if those people don't know someone who knows something, then I'm in trouble..." David

A wide range of personal networking strategies were reported. Examples include; always having resumes at hand and keeping them up to date, or ringing up contacts from the set when in work, rather than waiting to be out of work. This latter strategy can be seen as a way of demonstrating one's desirability as an employee; indicating usefulness as a contact who may have 'inside' information; and avoiding being seen as over instrumental ('[s]he only rings when [s]he wants something').

The importance of networking is such that it cannot be abstracted from the production task and maintaining one's network and seeking work becomes a central part of the job. A script supervisor felt it was the job;

"...finding and negotiating work is the hardest part. Doing the work is the fun. Finding the work is the job." Karen

Asked what she did during her free time the same respondent talked about spending time with friends, but then went on to qualify this;

“...most of my friends out here are in the business, and so when I say I hang out with my friends, half of that time is spent... 'well I heard about this, or did you hear about that', or 
you know, 'I've got something coming up', or 'you should send your resume to this one', or whatever. So seeing friends is looking for work sometimes..."

The importance of contacts was emphasised by a make-up artist who saw the resume as useless unless it can be 'walked in' by someone inside the production company:

“.. I have never gotten a job off sending someone a resume cold. Never, ever, and I have sent out hundreds of resumes, and I've never gotten a job that way, ever. I have only gotten jobs because I knew someone in the office who could walk my resume in, and I don't care if it was the lunch PA, if I knew someone who worked in that office and they could carry my resume in I would get an interview" Hany

She goes on to describe the importance of maintaining her network of contacts as it can prove an invaluable source of referrals:

“.. somebody picks up the phone and calls me, or I pick up the phone and I start calling my, you know, half a dozen friends who are in the industry working, to find out what they're doing $\ldots$ and tell them I'm not working right now ... because if they get a call they might refer me.”

As with the UK industry mentoring was seen as an important aspect of labour market operation and career development. Many interviewees reported having a mentor, while more experienced respondents reported taking on such a role. However, as noted earlier the US unions have a key role in controlling access to work, at least on the large productions. While they do not allocate work to individuals through the use of the roster, it does restrict the pool of labour from which employers are free to hire. 
Interviewees almost invariably viewed union membership as something to aspire to in order to gain the improved pay and conditions associated with employment under the union contract. This diverges form the UK sample who generally saw little benefit in union membership. At the same time, in the US, union membership offered further possibilities for networking and exchanging information about potential job opportunities, and for some this provided an incentive to attend union meetings.

\section{Conclusions}

On the basis of empirical evidence from the two localised labour markets described in the paper, 'place' is confirmed as having an effect on labour market processes. As Peck would argue, a complex interaction of shared and diverse features make up the labour markets examined in London ad Los Angeles. The informality of labour market processes defines both film labour markets, as does the use of particular types of connections such as family and friends. Institutions are a major determinant of labour market processes. The institutional variations which create geographical effects create opportunities and impose constraints on actors within localised labour markets, creating differences in labour market processes. The data reported in this paper would confirm the basic tenets of the local labour market approach to studying employment processes.

In terms of the industrial relations landscape, industry structure and training provision there are considerable differences to be observed in the institutional structures in which the Los Angeles and London film labour markets are embedded. These variations can account for the different ways in which interpersonal networks are built 
and the purposes towards which they are utilised. The film school entry route provided an additional means of developing contacts for the Los Angeles participants which, given the absence of similar educational provision in the UK, was not prevalent among the London freelances. Contacts can also be concluded to be used for slightly different purposes by each group of respondents. The importance of union certification to the Los Angeles freelances in gaining access to work on big budget, studio productions meant that working towards and maintaining union membership was significant. As access to even large studio productions in the UK is not dependent on union membership, no such imperative exists and so freelances do not gain and use contacts to build a CV in order to achieve union membership. Variation in training provision also generates different routes to skill acquisition for each group. Whereas in the UK training is predominantly on-the-job and therefore reliant on access to work, in the US the film school route (and subsequent internships) provide an additional path which may also expose entrants to contacts and enable network building.

While there are important differences in the institutional contexts within which freelances operate in the UK and US, a number of similarities are evident in career building patterns and networking behaviour which are largely attributable to the common structuring of the production process. In both contexts, the informality of recruitment and selection generates reliance upon networks of personal contacts for the transmission of information and work opportunities. The evidence from both groups of respondents illustrates the insufficiency of competency acquisition alone to successful career building, as interpersonal contacts are required in order to leverage that 'capital'. As the labour market is a social institutional rather than an abstract 
commodity market those social processes are confirmed as critical to the operation of the labour market. The dominance of each of the local labour markets by freelance employees is attributable to the broader industry structure in which project-baaed work is the dominant form. The resulting short-term employment relationships which form, tend to mean reliability is a key attribute sought in employees. Informal means are used in each of the labour markets to gauge that reliability, with familiarity either with the freelancer or a third party intermediary being an important factor in the decision-making process. So the common and widespread use of contacts within the Los Angeles and London film labour markets is a consequence of industrial structure and the common organisation of work rather than specific labour market institutions.

Analysis of the empirical data in this paper would confirm the usefulness of the local labour market approach to considering the observed similarities and variations in labour markets in different places. This is particularly the case as it allows a role for the complex interaction of social forces and power relations at different levels of analysis and in different geographical places. 


\section{References}

BECTU (1994). The British Film Industry: Memorandum to the National Heritage

Committee. London, 9 September

BECTU (2000). About BECTU, BECTU.

Blair, H. (2000). You're only as good as your last job: the relationship between labour market and labour process in the British film industry. Hatfield, University of Hertfordshire.

Blair, H. (2001a). "Interpersonal Networks in Conditions of Uncertainty: the case of film production in Britain.” Regional Studies forthcoming.

Blair, H. (2001b). ""You're Only as Good as Your Last Job": the Labour Process and Labour Market in the British Film Industry." Work, Employment and Society 15(1): $1-21$.

Blair, H., Grey, S. and Randle, K. (2001). "Working in Film: Employment in a project based industry." Personnel Review 30(2): 170-185.

Blair, H. and Kerrigan, F. (2001). A New Era or a Recurring Pattern? An analysis of current trends in European and British film-making. Advances in Communication and Media Research. F. Columbus. New York, NovaScience. 1.

Boyer, R. (1990). The Regulation School: A Critical Introduction. New York, Columbia University Press.

Christopherson, S. (1996). Flexibility and Adaption in Industrial Relations: The Exceptional Case of the U.S. Media Entertainments Industries. Under the Stars: Essays on Labor Relations in Arts and Entertainment. L. Gray and R. Seeber. Ithaca London, Cornell University Press: 86-112. 
Christopherson, S. and Storper, M. (1989). "The Effects of Flexible Specialization on Industrial Politics and the Labor Market: The Motion Picture Industry.” Industrial and Labor Relations Review 42(3): 331-347.

Coe, N. M. (2000). "The view from out West: embeddedness, interpersonal relations and the development of the indigenous film industry in Vancouver." Geoforum 31: 391-407.

DeFillipi, R. and Arthur, M. (1994). "The Boundaryless Career: a competency based perspective.” Journal of Organizational Behaviour 15: 307-324.

DeFillippi, R. J. and Arthur, M. B. (1998). "Paradox in Project-Based Enterprise: The Case of Film Making." California Management Review 40(2): 125-139.

Doeringer, P. and Piore, M. (1971). Internal Labour Markets and Manpower Analysis. Lexington, Heath Lexington Books.

Edwards, R. (1979). Contested Terrain: The Transformation of the Workplace in the Twentieth Century. London, Heinemann.

Ellis, J. (1992). Visible Fictions. London, Routledge.

Department of Culture, Media and Sport (1998). A Bigger Picture. London, March

Gordon, D. M., Edwards, R. C. and Reich, M. (1982). Segmented Work, Divided Workers: The Historical Transformation of Labor in the United States. Cambridge, Cambridge University Press.

Granovetter, M. (1985). "Economic Action and Social Structure: the Problem of Embeddedness.” American Journal of Sociology 91: 481-510.

Granovetter, M. (1995). Getting a Job. Chicago and London, University of Chicago Press. 
Gray, L. and Seeber, R. (1996). The Industry and the Unions: An Overview. Under the

Stars: Essays on Labor Relations in Arts and Entertainment. L. Gray and R. Seeber. Ithaca London, Cornell University Press: 15-49.

Grieco, M. (1987). Keeping it in the Family: Social Networks and Employment Chance. London, Tavistock Publications.

Jones, C. (1996). Careers in Project Networks: The Case of the Film Industry. The Boundaryless Career: A New Employment Principle for a New Organizational Era. M.

B. Arthur and D. M. Rousseau. New York

Oxford, Oxford University Press.

Jones, C. and DeFillipi, R. J. (1996). "Back to the future in film: Combining industry and self-knowledge to meet the career challenges of the 21 st century." Academy of Management Review 10(4): 89-103.

Jones, C. and Walsh, K. (1997). "Boundaryless Careers in the US Film Industry: Understanding Labour Market Dynamics of Network Organizations.” Industrielle Beziehungen 4(1): 58-73.

Langham, J. (1996). Lights, Camera, Action: Working in film, television and video. London, BFI Publishing.

Malhotra, N. K. (1996). Marketing Research: An Applied Approach. New Jersey, Prentice Hall.

Bridge Media (1994). Factors Influencing the Production, Supply and Exhibition of Independent Films in the UK Market. London, April

Paul, A. and Kleingartner, A. (1994). "Flexible Production and the Transformation of Industrial Relations in the Motion Picture and Television Industry." Industrial and Labor Relations Review 47(4): 663. 
Peck, J. (1996). Workplace: the social regulation of labor markets. New York and London, The Guilford Press.

Pfeffer, J., Salancik, G. and Leblebici, H. (1976). "The Effect of Uncertainty on the Use of Social Influence in Organizational Decision Making." Administrative Science Quarterly 21: 227-245.

Picchio, A. (1992). Social Reproduction: The Political Economy of the Labour Market. Cambridge, Cambridge University Press.

Polyani, K. (1944). The Great Transformation: The Political and Economic Origins of our Time. Boston, Beacon Press.

Randle, K. and Culkin, N. (2000). "A Perfect World for Capital": Hollywood in the era of 'runaway' production. 18th Annual Labour Process Conference, University of Strathclyde.

Rubery, J. (1994). “The British Production Regime: A societal-specific system?" Economy and Society 23: 335-354.

Skillset (1996). A Career in Broadcast, Film and Video. London, January

Tepper, R. (1999). How to get into the entertainment business. New York, Wiley.

Whitney, A. (2001). "British studio merger will create a rival for Hollywood". The Independent, London. 12 February,

Wial, H. (1991). "Getting a good job: Mobility and segmented labor markets." Industrial Relations 30(3): 396.

\footnotetext{
${ }^{i}$ Employees are categorised as "above" or "below the line." Above the line employees are thought of as creative talent; while, below the line generally refers to technicians and support services (although it includes set designers and artists). The "line" is an accounting demarcation used in developing the budget for production. Some above the line costs are incurred even before a film goes into the production stage. Above the line costs include the story rights, the screen play, the producer, the director, and the principal cast.
} 
${ }^{\text {ii }}$ TeenComedy is a pseudonym used to conceal the identity of the case study production.

iii This refers to the practice of providing individuals who have worked on a production with a video copy of the product, and of formally acknowledging their contribution. Credits are an important legal requirement in establishing entitlement to a share of any profits that might be made by the film where there is an agreement for deferred payment. They are similarly required in order to be entitled to 'residuals' (residual or supplemental payments) - income generated when a work is reissued in another medium (e.g. $35 \mathrm{~mm}$ film to video or to television) 